Bryant University

Bryant Digital Repository

2006

\title{
Enforced Tourists: American Women, Travel, and the 'Far-Flung Fronts' of World War II
}

Judy Barrett Litoff

Bryant University

Follow this and additional works at: https://digitalcommons.bryant.edu/histss_jou

\section{Recommended Citation}

Litoff, Judy Barrett, "Enforced Tourists: American Women, Travel, and the 'Far-Flung Fronts' of World War II" (2006). History and Social Sciences Faculty Journal Articles. Paper 36.

https://digitalcommons.bryant.edu/histss_jou/36

This Article is brought to you for free and open access by the History and Social Sciences Faculty Publications and Research at Bryant Digital Repository. It has been accepted for inclusion in History and Social Sciences Faculty Journal Articles by an authorized administrator of Bryant Digital Repository. For more information, please contact dcommons@bryant.edu. 
St. Louis Railroad Station -- July 29, 1944

It's 1:25 a.m. and here I sit, practically alone, waiting for 8:00 a.m... Oh yes, I missed my train in Cincinnati this morning by two minutes....Another girl missed the train, too, and we had a gay time walking around Cincinnati....All my life I've wanted something interesting like this to happen to me, and it has.... This is really a trip for the books.

Frances Zulauf to Lt. Robert Zulauf (World War II Letters of United States Women)

I. American Women as Enforced Wartime Tourists

Approximately twenty percent of the United States population was on the move during World War II as one of the major demographic shifts in American history took place. The U.S. Census Bureau estimated that 15.3 million civilians moved, over half of them across state lines. In addition, the 16 million American citizens who served in the military traveled to distance posts around the nation and the world. As Gerster and Pierce have established, "Travel is a political as well as recreational action... [and] is fundamental to the war experience." (Gerster and Pierce, 2004) Viewed within this context, war becomes a facilitator rather than an inhibitor of travel. 
Utilizing my archive of some 30,000 letters written by civilian and military American women during the Second World War, this paper demonstrates how the cataclysmic events of that war expanded the geographical centers and states of knowledge of these women both at home and abroad as they traveled to distant and remote areas, met new people, took on new jobs, encountered different cultures and ways of life, and established themselves and their families in unknown locations. (Bennet, 1943; Fowler, 1943; Packard, 1944, Soldiers' wives give up home and job for camp life with husbands, 1942) Women's wartime letters provide perceptive insights into heretofore unexplored but fundamental aspects about wartime travel. These letters are honest accounts written "at the scene" and for a limited audience and with little idea that scholars would one day be interested in their content. Better than any available primary source, they capture the emotions and experiences of the millions of American women who can rightly be described as enforced wartime tourists.

Despite the wide-ranging significance of women's wartime travel, scholars have paid only scant attention to these enforced tourists and the challenges that they encountered. While important studies about late-nineteenth and early twentieth-century women travelers have been published, these works have focused on women's selfpropelled, leisure journeys of exploration and self discovery. (Allen 1998; Harper, 2001; Mills, 1998; Pratt, 1992; Smith, 2001; Wesley, 1999) By contrast, the wartime travels of World War II women were forced upon them by the unparalleled events of the war years. Women traveled to remote destinations for practical and specific reasons: to be near 
loved ones, to seek out new jobs, or to assume assignments at military postings. On those occasions when recreational travel did occur, it usually came about as a consequence of the exigencies of the war - not because women were seeking out leisure travel.

In their letters to friends and loved ones, United States women regularly commented on their enforced travels and new circumstances as well as their changing and expanding geopolitical horizons. Letter writers mapped out the events of their daily lives in their letters as they sought to prepare loves ones for the changes they were undergoing. They provided detailed descriptions of their growing sense of their place in the world, and they solicited information from correspondents about new and unusual experiences. Distant geographical place names, such as Anzio, Okinawa, Dresden, Stalingrad, and Yalta, were incorporated into everyday vocabulary. Indeed, the billions of letters exchanged during the wartime years helped to minimize the distinctions between the separate and often disparate domains of the letter writers and recipients.

\section{Service Wives as Enforced Wartime Tourists}

Service wives often traveled thousands of miles to be with their military husbands. They journeyed from small towns to sophisticated metropolitan centers and back again. A reporter for the New York Times Magazine described these women as "wandering members of a huge unorganized club." They recognized each other on sight, exchanged views on living quarters, babies, and allotments, demonstrated pride in their 
husbands, and helped each other in times of difficulty. War wives banded together and made life, if not pleasant, tolerable. (Benjamin, 1943; Green and Murphy, 1943; Maulsby, 1945; Navy wives at Key West, 1943; Island of Navy wives, 1942; Valentine, 1944) Women could find a great deal of advice in the press on how to ease the difficulties of traveling. They were told what to pack and "how to live in a trunk." (Beveridge, 1944; Gordon, 1943; Holbrook, 1944; How to live in a trunk, 1942; Kas and Thompson, 1944)The special problems associated with traveling on crowded trains and busses with young children were widely discussed. Mothers were exhorted to avoid the logistical problems associated with carrying too much luggage, but at the same time, to bring sufficient diapers, bottles, baby food, and other necessities.(Kenyon, 1945; Shultz, 1943; Shultz,1945; US Department of Labor, Children's Bureau Publication no. 307, [n.d.]) While preparing for a long train trip with her two-month old daughter to join her Army Air Corps husband at his posting in Louisiana, a young Georgia war wife wrote, "I shall bring as little as possible -- now, I will need the cover for her cradle, won't I?" Four days later, she remarked, "I need more than my two bags for both our things. I may send the coffee maker and bassinette on ahead of me. You have an alarm clock, don't you? Let me know." (Litoff, et al., 1990, 114)

Not everyone agreed that service wives should follow their husbands to military bases. Citing the pressures on already overcrowded travel facilities, the Office of War Information urged wives to remain at home. At least some observers described those women who went anyway as "selfish," pointing out that prices were high and conditions 
near military camps far too crowded. Wives often arrived at bases just as their husbands were about to be shipped overseas. Nevertheless, most wives felt it was important to be with their husbands as long as possible. (Hohman, 1943; Office of War Information, A question of wives, 1944; Sweedy, 1943)

\section{Geopolitical Disruptions and Dislocations}

The sense of time and space of young war brides living in Hawaii at the time of the Pearl Harbor attack was suddenly and irrevocably disrupted by the events of December 7, 1941. In a December 8 letter to her sister, one young war bride, Fern Steuteville Wilson, vividly described the onset of hostilities on her life and how her sense of personal space within the home had been threatened by the Japanese attack:

I hope you will excuse me for not writing yesterday. At least I can say that I saw the very beginning of it....At 8 a.m. a blast woke us up and Jack said, "The damn Navy is practicing bombing over Hickam [Field] because it's Sunday morning."... We jumped out of bed and it was a sensation to see a plane coming out of a dive almost even with the bedroom window....Jack yells, "It's the Rising Sun!" I didn't know what he meant, it was 8 a.m. so why the sun shouldn't be rising. Then he said, "It's the Japs!" At that minute my heart started pounding like a trip hammer and kept it up until I 
woke up this morning.... (World War II Letters of United States Women)

Over the course of the next four years, the dislocations precipitated by the events of December 7 would reverberate in the lives of women throughout the United States. Following a whirlwind courtship, Audrey M. Savell resigned from her job as a librarian at Fort Dix, New Jersey and traveled across the continent by train to marry her fiancé, a career Navy man stationed at Coronado, California. In March 1945, she accepted a position at the Presidio in San Francisco, where she was appointed Chief of Training and Inspections for the Army 9th Service Command. The exhilaration and trepidation that she felt about her new job were the focus of her March 16, 1945 letter to her husband:

I'm so terribly excited I can hardly hold the pen! This afternoon Mr. Xenophon Smith from [the Presidio in] San Francisco phoned and wants me to take a job up at headquarters, in his office -- and what a job! I'm positively shattered when I think of the responsibility of it! It will consist equally in training new librarians to replace the 24 on this command who are already going overseas and more to follow, and travelling all over the Service Command giving the libraries a technical inspection. Gad, me! I'm thrilled and scared all at once, but I just can't see turning it down.... (Litoff and Smith, 1991, Since You Went Away, 166-171) 
Audrey Savell made one major move during the war years. Other war wives became modern-day "camp followers" as they crisscrossed the country with their service husbands. (Klaw, 1943; Mayberry, 1984) In a November 1, 1944 letter to her Marine husband, in which she reminisced about their travels in Virginia, North Carolina, and California prior to his shipment to the Pacific Theater, Marjorie Killpack of Ogden, Utah wrote: "Do you remember the broken bed at Mrs. Royens and how damn squeaky it was. Also, the bed we broke down at Mrs. Kelly's in Quantico. Gee, we've sure left a `trail of broken beds' behind us." (Litoff and Smith, 1991, Since You Went Away, 100-102)

Women separated from their fiancés by wartime exigencies traveled alone to meet future in-laws, and wives made frequent journeys to the homes of their husbands' families. Women also traveled great distances for brief rendezvous with sweethearts and husbands. The lobby of the St. Francis Hotel in San Francisco and under the clock at New York City's Grand Central Station were two legendary meeting places. Perhaps the most poignant journeys of all were the hurriedly arranged and occasionally clandestine trips to ports of embarkation to say good-bye.

Uprooted war wives faced many new challenges and were sometimes required to adapt to entirely new ways of life. For example, Lilian Selinkoff of Wilmington, Delaware followed her Army husband to his assignment in the Canal Zone. Her letters to friends in Wilmington included a report of her attendance at a Jewish wedding where the marriage canopy was made of palms and lilies. She also wrote about making borscht from canned spinach and beets and preparing gefilte fish from local fish, such as corbina, 
ocean perch, and snook. As she said in one letter, "We even serve it to goyim when they come to dinner." (Sklut, Mollye Papers)

While most wartime separations occurred when loved ones were inducted into military service, the events of the war resulted in forced separations of a very different type for Americans of Japanese descent. In 1942, the 120,000 Japanese-Americans living along the West Coast were evacuated to camps located in remote areas of the United States. This relocation process sometimes resulted in painful separations. Sonoko Iwata and her three young children were sent to the Colorado River Relocation Camp near Poston, Arizona while her husband, Shigezo Iwata, was detained at the Lordsburg, New Mexico Internment Camp. After writing an appeal to Attorney General Francis Biddle in which she "solemnly affirm[ed]" that her husband had "at all times been loyal to America and had always cooperated with our government: and that to be considered otherwise was "a dishonor which we cannot bear to face," the family was reunited at Poston in July 1943. In letters written to her husband during their sixteen-month separation, Sonoko Iwata described the task of building a new community in the Arizona desert as well as the difficult personal adjustments she faced. Yet in a March 5, 1943 letter, she found the emotional strength to state: "You know, I was thinking today that time marches on and if I'm to keep up, we should bury the past and always look toward what's coming." (Litoff and Smith, 1991, Since You Went Away, 213-223)

IV. Uprooting of Women from "Traditional” Female Rolls 
The pressing demands of the Second World War also resulted in the uprooting of women from "traditional" female roles. With the decline of the rural population of the United States as farmers joined the military or sought more lucrative work in war industries, an estimated three million nonfarm women took on farm jobs between 1943 and 1945. (Litoff and Smith, 1993) Following a train trip through rural Arkansas, Mabel Opal Miller reflected on the changing wartime landscape of rural America. In a September 6, 1944 letter which she sent to her Army Air Corps boyfriend, she observed: "I noticed on the farms, mostly the little ones with just a shack for a home, there seems to be no one but the women left to do the work. You see them out taking care of cattle, etc. It makes one proud to see how the women have picked up where the men left off and are keeping the home fires burning." (Litoff and Smith, 1991, Since You Went Away, 208-

The landscape of industrial/urban America underwent equally striking changes during the wartime years as the proportion of women in the work force increased from 25 percent at the beginning of the war to 36 percent at the war's end.(Campbell, 1984, 101138; Hartmann, 1982, 77-100) After securing a job at a nearby shipyard, Polly Crow of Louisville, Kentucky proudly proclaimed to her Army husband: "You are now the husband of a career woman -- just call me your little Ship Yard Babe!" She described the "grand and glorious feeling" of opening her own checking account, gas rationing and automobile maintenance, the many "wolves" on the swing shift, and what it felt like to 
join a union. Late in 1944, upon learning that the work of building Landing Ship Tanks at the shipyard would be completed within the next few months, she wrote a letter in which she bemoaned the fact that "my greatly enjoyed working career will come to an end." (Litoff and Smith, 1991, Since You Went Away, 146-152)

\section{Military Women as Enforced Wartime Tourists}

Unanticipated avenues for enforced travel and adventure opened up for the nearly 400,000 American women who profited from the opportunities to don military uniforms. When writing to loved ones, women in uniform provided detailed commentary about their new circumstances that included descriptions of encountering different customs, cultures, food, and languages as well as visiting local tourist attractions.

Women's Army Core (WAC) Private Katherine Trickey of Lewiston, Maine was stationed at Camp Wheeler, Georgia. When writing to her mother, she often commented on her experiences as a northerner living in the South. The sweltering heat of Georgia's summers did not go unnoticed by this Maine native. During one particularly hot spell in August, she wrote about a "watermelon party in the barracks day room" in which "we spread papers all over the floor and about a dozen of us crowded around. Messy oh my, juice and seeds and rinds all over that paper!.. More fun.” Yet as delightful as Georgia watermelon parties were, she still missed the cool summers in Maine, telling her folks 
that she had received “your letter written `on a high hill in Maine.' Wouldn't I have liked to be with you. It sounded so inviting. I bet the blueberries will taste good."(World War II Letters of United States Women)

On March 6, 1944, she wrote of a day trip that she and five other WACS took to see the peach trees in full bloom:

You have heard, undoubtedly, of Georgia as the Peach State. Yesterday, I found out why. Six of us hired a car and drove to Fort Valley to see the peach blossoms. It was the Sunday when they were in full bloom and we had been told it was a sight worth seeing. There are acres of trees. The pink blossoms against a background of a heavenly blue sky was a sight I shall never forget. (Litoff and Smith, 1994, 82-93)

Trickey wrote to her parents about going to performances at the nearby Little Theater of Macon, Georgia as well as the Macon Opera, attending a lecture by World War I flying ace Eddie Rickenbacker, preparing for a visit by Colonel Oveta Culp Hobby, Director of the WAC, and befriending young soldiers at the local USO club where she danced to wartime swing music. She commented on the warmth of southern hospitality during trips to Atlanta where she walked down Peachtree Street and visited the famous Atlanta Cyclorama, a large circular painting and diorama dating from the late nineteenth century that depicts the 
Battle of Atlanta, but she also expressed indignation at the extreme poverty of the Negro sections of southern towns.(World War II Letters of United States Women)

As a member of the Army Nurse Corps, Marjorie La Palme was sent to England, in June 1942, where she worked at a military hospital. La Palme's mother had been a World War I British war bride, and La Palme wrote with excitement about traveling to Derbyshire to meet with her maternal grandmother for the first time. Following the DDay invasion of June 6, 1944, La Palme was transferred to an evacuation hospital that followed the 9th Army through France, Belgium, Holland, and Germany. During her thirty-nine months of overseas duty, she was often near the front lines of battle. In mid December 1944, she wrote a graphic letter to her mother in which she described the Battle of the Bulge:

The buzz bombs have stopped for awhile but enemy planes come over and then the ack ack guns start - we see flashes and explosions all along the horizon - we are very close to the fighting.

Everywhere through all these countries we see the havoc of war piles of bricks and rubble - streets and streets of it - once homes and public buildings, bridges bombed....Not just a few homes but the entire city is gone....

It was a terribly exciting night last night - so much activity all over the place - many enemy planes over head - we could hear them strafing - 
explosives and mortar fire continually all the night long....The weather is frigid cold and snow is deep. My heart goes out to our poor boys out there in the dark and cold. (World War II Letters of United States Women)

Military women stationed in the Pacific Theater of War found the different languages and customs of that region of the world to be especially striking. Army nurses who were evacuated to Australia following the collapse of the U.S.Filipino military effort in the Philippines in the spring of 1942 wrote of visiting sheep stations, drinking an enormous amount of tea, and learning to "talk Australian." (Litoff and Smith, 1994, 180-181) Military women stationed in New Guinea emphasized the "exotic" nature of life in the South Sea Islands. Upon her arrival in New Guinea in September 1944, WAC Private Betty Donahue wrote a letter to her family that reflected the sentiments expressed by many military women stationed in the South Pacific:

Your wandering gal has finally come to rest in her South Sea Island Paradise....Gad, is it hot here - The perspiration just rolls off you when you just sit in your underwear - Oh, well, I came to do a job and I can do it out as well as the next guy....This is really a very interesting place -coconut palms, grass houses, odd shells on the beach, huge trees with roots that spread for a half a block and natives with red hair and rings thru their 
noses -really things I never expected to see. (Litoff and Smith, 1994, 190)

WACs stationed in the South Pacific also wrote at great length about the mosquito problem and the threat of catching malaria. Sergeant Frances Harden, who arrived in New Guinea in the fall of 1944, took compulsory doses of atabrine as protection against malaria, for "little Annie," the nickname for the anopheles mosquito, was everywhere. Her letters included comments about her "atabrine tan" as atabrine caused the skin to turn various shades of yellow. In one letter she joked, "If all the atabrine pills we've taken were laid end to end, they'd make a 'G String' big enough for Mother Earth.” (Litoff and Smith, 1994, 186)

American Red Cross women who worked at overseas assignments in the ChinaBurma-India Theater of War composed lengthy letters to their loved ones that described the radically new experiences they were now encountering. A Red Cross worker stationed in Calcutta wrote about visiting "palaces, temples, and some not so pleasant places" as well as going on an evening picnic with "lights from native fires reflected in the river, and the sound of drums beating in the distance. [It was] one of those exotic, breath-taking nights that...only the East can produce because beneath the apparent calm lies an exciting sense of terror produced by wild animals' eyes, and noises as well as the delightful uncertainty about the temper of the natives." (Litoff and Smith, 1994, 197, 206, 208) After flying from Calcutta over "The Hump" to Kunming, China early in 1944, American Red Cross worker Rita Pilkey of Dallas, Texas penned long letters to her 
parents that were filled with descriptions of Chinese life, her meetings with Chinese dignitaries, such as Madame Chiang Kai-shek, and information about her Red Cross work in the remote region of Yunan Province In March 1944, she wrote about learning to fire guns in small arms class because, as she noted in another letter, "when you drive any place away from the base you are on, you always take a gun because of the bandits." In November 1944, after being selected to set up the first tent facility at a new base, she told her parents that "I like it here, but I feel honored to be chosen to go there because it is supposed to be the hardest place here [in China]" (Pilkey, Rita Papers)

The letters of Martha Alice Wayman, a WAC lieutenant who was stationed in the Philippines during the first ten months of 1945, are replete with the difficulties she encountered living in a tropical, recently liberated, war-torn community. Writing to her family in the United States, she emphasized that the streets of the Philippines were the muddiest she had ever seen and that the mosquitoes were so bad that she had to wear a strong repellent as well as sleep under a net. She wrote that the hot, damp weather had caused many of her leather goods, including the inside of her typewriter case, to turn green from mold. She included considerable commentary on the poverty of the Filipinos who walked barefoot through the countryside and lived in thatched huts or little wooden shacks, but she also emphasized that her encounters with the natives were always friendly. (World War II Letters of United States Women)

In March, Wayman was transferred to Manila where she worked in a 
burned-out building with patched holes. She recounted stories of the Japanese atrocities that she heard from the natives and remarked on the stench associated with bombed and crumbling buildings where dead Japanese bodies lay rotting. But her letters also included accounts of eating delicious Filipino fruits such as papayas and mangos and the beautiful native orchids that flourished around Manila. (World War II Letters of United States Women)

The following October, with the war now over, Wayman was one of the first WACs to be transferred to Japan to serve with the occupation forces. She wrote to her parents that her flight to Tokyo provided her with a bird's eye view of the "destruction caused by Allied bombing." She noted that "many places [in the city] were completely destroyed - for blocks at a time - and others were scarcely touched." (Litoff and Smith, 1994, 243-244) Over the next several months, she recounted visiting numerous Buddhist shrines and the thrill of seeing Mt. Fujiyama for the first time. She described having dinner in a Japanese home where she ate with chopsticks and sipped sake, and she also provided an account of attending a "high-type" geisha party where three geisha girls who wore "very lovely kimonos and obis" attended her. (World War II Letters of United States Women)

Military service also enabled African Americans to travel to distant places, meet new people, take on new jobs, and confront new challenges. For both black women and men, however, this almost always occurred within segregated units. Harriet M. West, an 
African-American member of the Women's Army Corps, reported on the problems routinely encountered by black WACs traveling in the south. She wrote that the segregated railway coaches they were assigned to were "filthy" and the seats were "black and grimy." She emphasized that railroad workers used "very vile names" and the "most obscene language" when addressing them, often jeering at them and calling them "Niggers." (Litoff and Smith, 1994, 72-74)Despite the segregation and discrimination experienced by blacks in the military, the African-American community demonstrated strong support for the ideals for which World War II was fought, adopting the "Double V" campaign calling for victory over totalitarianism abroad and victory over racism at home.

VI. Imagined and Vicarious Travel for Women on the Home Front

For women who remained at home during the Second World War, the opportunities for imagined and vicarious travel were widespread. One young war wife from New Athens, Illinois wrote to her recently departed husband and said, "I know that with every minute you're going farther away from me. I figure that you are somewhere in Texas now, Darling."(Litoff and Smith, 1991, Since You Went Away, 14-15) Isabel Kidder of Durham, New Hampshire expressed similar sentiments when she commented, "My darling, I call this the first day, for it is the first day in which I do not know where you are. If your ship slipped out into the wideness of ocean last night, to-night, or 
tomorrow, I shall not know until after the war probably." (Litoff and Smith, 1991, Since You Went Away, 93-100) Indeed, the themes of separation and distance regularly occurred in the letters written by women during World War II.

In their efforts to bridge the miles which separated them from loved ones, war wives often set aside a special time each evening to write letters to husbands stationed far from home. As one letter writer commented, this was "the best time of each twenty-four hours." From the seclusion of their bedrooms, women recalled past events, included information about the day's activities, discussed the whereabouts of relatives and friends, and even symbolically smoked "the last cigg before cutting the light off" just as they had done before the separation. (Litoff et al., 1990, 143-145)

Women on the home front listened to radio broadcasts about the war, watched news reels and movies, and carefully read newspaper and magazine articles which reported on the activities of United States forces scattered around the world. The columns of well-known journalists, such as Ernie Pyle, Richard C. Hottelet, and E. J. Kahn, Jr., were scrutinized for information concerning the whereabouts of relatives and friends. In a January 31, 1945 letter, Catherine Pike of Esmond, Rhode Island informed her husband, who was engaged in heavy combat with the allied forces in Europe, that "I even know where you are exactly by following the news closely." Seven weeks later she wrote, "George, you'd be surprised if you knew how much I know about the war, how much reading I do about it, and how well I can talk about it." (Litoff and Smith, 1991, Since You Went Away, 82-91) 
Newspapers and magazines regularly published detailed maps of the events taking place in the various theaters of war. Public buildings, such as schools and post offices, featured war maps on their bulletin boards. Moreover, maps lined the walls of many American homes as armchair strategists marked the advance of allied forces. In late October 1944, Saidie R Leach of Edgewood, Rhode Island wrote to her son, Douglas, stationed with the Navy in the Southwest Pacific, and told of hanging "the new geographic map of your part of the world...in the 'bulkhead' over the kitchen radiator" and placing the pins in Leyte, but she also noted that "the unconquered territory still looks huge!" (Litoff and Smith, 1991, Since You Went Away, 188) The war maps of Keith Frazier Somerville of Cleveland, Mississippi even spread onto the walls of her bathroom, and she noted in her wartime journal, "Now I have to stand in the tub to follow the African campaigns and we... go so far as to conduct guests into the Maproom." (Somerville, 1943)

Across the United States, women envisioned both the extraordinary and quotidian events encountered by loved ones stationed at "far flung" fronts. Flora Southwick of Marietta, Ohio wrote to her husband, who was assigned to the Supreme Headquarters Allied Expeditionary Force in England, while she listened to the D-Day broadcasts from the beaches of Normandy. As a former newspaper reporter for the Marietta Times, she used her journalistic acumen to visualize the events of the invasion even though she could not be there: 
June 6, 1944

Dearest Darling:

Today we have lived history. I can't even describe my sensations when I turned on the radio this morning. Somehow there is a feeling of relief that things have actually started....

I guess my old newspaper days got the better of me this morning when I was listening to the radio. I fairly ached to be there and see it all with my own eyes. Even the possible loss of one's life seemed a small price to pay for being part of one of the biggest things in history. If a man survives he will always know that he made history. If he does not, he went out in a supreme moment and there is something to be said for going that way...

Devotedly, Flora (Litoff and Smith, 1991, Since You Went Away, 111-118)

Service wives often contemplated what combat conditions were like for their husbands. One young war wife wrote, "As I hung out Georgie's wash this a.m. my hands became so cold that I could hardly move them. It made me think about you. Gosh, Honey, how can you shoot when your hands are stiff? I wonder if you'd like me to send you a couple of pairs of gloves? You could wear them when you're not shooting maybe." (Litoff and Smith, 1991, Since You Went Away, 82-91)

As women confronted the harsh realities of war, they could not avoid envisioning 
the personal tragedies that might and did occur. Josephine Keutman, a fifty-three year old widow from the Bronx, New York, wrote an emotional and heart-rending letter after learning that her only son had been listed as missing in action following his failure to return from a bombing mission over Poland.

October 25, 1944

To My Darling (where ever you are, come back to me.)

Today is exactly 6 weeks that you went on that fatal mission. Maybe some miracle or gift of God has happened that will enable you to come back to your base or maybe home. God only knows how I am worrying about you so far away from home and maybe being tortured or sick or even wounded...

While I am writing I am being blinded with tears which are running faster than the pen is writing.....I miss you much, my heart is broken.

Love, Mom (Litoff and Smith, 1991, Since You Went Away, 258-261)

The return of loved ones from combat provided still another opportunity for women on the home front to ponder and envision the battle front experience. Margaret Barrow of West Point, Georgia wrote a joyous letter when she learned that her Navy son, who had been wounded in battle, had arrived safely in California. 
May 14, 1944

Dearest Jody Boy:

Cannot find words to express my joy to know my sweet boy is actually back in the U.S.A. Still have to stop and think at intervals if it is really a fact, or am I dreaming....

Bet you are confused and mixed up about the "states." All of the boys coming in from the Pacific area seem to be. It must be very primitive and rugged out there. It will seem wonderful to be back in civilization again after you get "adjusted" to we queer beings, the "civilians".... Lovingly, Mother (Litoff and Smith, 1991, Since You Went Away, 190-194)

Of course, thoughts of death and mayhem did not occupy all of women's musings as they contemplated the experiences of loved ones at war. After reading letters from her Army Air Corps husband stationed in England, Marjorie Gaunt of Cranston, Rhode Island remarked: "You must be getting real British cycling around and dining in tea rooms. Do those places look like you expected them to look? When you write those things, I have a definite picture in mind...." (Litoff and Smith, 1991, Since You Went Away, 248-252)

As one might expect, questions relating to fidelity and love sometimes emerged in the minds of service wives who were separated from their husbands. When one Army husband failed to report fully about his furlough in Paris, a city once described as the 
"silver foxhole," his young war wife, Barbara Wooddall Taylor of Fairburn, Georgia, scolded him with the following "choice" remarks:

You probably didn't have time to write me while you were in Paris -- and for that I don't blame you one bit. Although there was one short paragraph about the trip, I gather you had a nice time. What if I should go to the mountains or beach and when I returned say just a few words like you did. You'd probably think the same things I am thinking right now and I would doubt it if you would like it even as much as I. Do I make myself clear ole top? Since we are miles apart with an ocean between us there isn't a helluva lot I can do about it -- as you well know. I am glad that you are "rested mentally" -- must be a great feeling -- wouldn't know for ten months is a long time -- and as you have told me, "It's all in your mind, Barbie" -- and who knows?? You could be right about it! (Litoff, et al., $1990,147-148)$

VII. The Coming of Peace and Women's Growing Geopolitical Consciousness

The coming of peace in August 1945 provided further opportunities for women at home to visualize events taking place around the world. One young war bride wrote an 
exuberant letter to her soldier husband in France and exclaimed: "THE WAR IS OVER....Mother and I were listening to the radio when the news first came on -- and we were laughing and crying together. I kept saying, 'I want to go to Paris' -- meaning, I wanted to go on the air by radio -- and sure enough -- we did go to Paris -- and I felt as if we were there together." (Litoff, et al, 1990, 284-285)

In their correspondence, women of the World War II generation readily acknowledged that both they and their loved ones had been dramatically changed by the events of the war. Writing from the Mississippi Delta at the end of August 1945, Keith Frazier Somerville offered some succinct observations on these changes:

We have lived with war so long--it almost seems forever! It's even hard to remember a time when we weren't hanging over the radio for "the news."... This has been such a horrible war, and so far flung that even we noncombatants, who have suffered not at all, are exhausted emotionally and mentally trying to keep up with it, do our small parts, and try not to worry. We've lived on a tension for so long that it's going to be hard for all of us to relax. (Litoff and Smith, 1991, Dear Boys, 243-245)

On a more personal level, Edith Speert, a supervisor of a federally funded day care center in Cleveland, Ohio, wrote a forthright letter to her husband on October 21, 1945 and declared: I must admit I'm not exactly the same girl you left -- I'm twice as 
independent as I used to be and to top it off, I sometimes think I've become 'hard as nails'.... Also -- more and more I've been living exactly as I want to and...I do as I damn please." Three weeks later, Speert reiterated her concerns:

Sweetie, I want to make sure I make myself clear about how I've changed. I want you to know now that you are not married to a girl that's interested solely in a home -- I shall definitely have to work all my life -- I get emotional satisfaction out or working; and I don't doubt that many a night you will cook the supper while I'm at a meeting. Also, dearest -- I shall never wash and iron -- there are laundries for that! Do you think you'll be able to bear living with me? (Litoff and Smith, 1991, Since You Went Away, 152-159)

The events of the Second World War also contributed to women's growing geopolitical consciousness. During the final months of the conflict, women's letters were punctuated with astute comments about the complexities of world politics and their hopes and dreams for the postwar world. Following the Russian declaration of war on Japan on August 8, 1945, Kay McReynolds, a senior at the University of Missouri, wrote to her fiancé and announced: "My next to the favorite country is Russia....Isn't it wonderful? It will bring the end of the war sooner, but I'm not one of these optimistic souls who are saying that it may be over in two or three weeks. But, with the atomic bomb, maybe we 
won't have to lose so many lives in an invasion." (Ltioff and Smith, 1991, Since You Went Away, 47-52)

In their victory letters, women wrote of the ecstasy and euphoria of peace while acknowledging that the new atomic age had unleashed many enigmatic challenges. Edna Golan of New York City expressed these ideas with exceptional clarity when writing to her Army husband in Europe:

August 9, 1945

My Love:

Can you feel the brilliant sunshine on this page? And the peace? And hear the splashings of the summer? And the laughter of the children?...And the goldenrods, and the lovely bushes and trees all along the edge of the water?...

For the events of these last four days give great reason for....optimism what with the atomic bomb and the announcement of Russia's declaration of war on Japan. As far as the atomic bomb is concerned, my Darling, I can see where the end of fighting for us might be sooner, but it's a great sacrifice, my Darling, for this really seems to be, the beginning of the end of all civilization....

Your own, Edna (Litoff and Smith, 1991, Since You Went Away, 65-74) 
In an August 18, 1945 letter to her future husband, Constance Hope Jones of Kirkwood, Missouri presented a perceptive analysis of the fragile and transitory nature of the politics of peace and the coming of what would eventually be called the Cold War:

Now, I suppose President Truman and Congress really have a big job of getting things and people adjusted to peace time ways of hiring and doing! Perhaps the biggest job is yet ahead. Over the radio yesterday....I heard the starting of another war! All about how the U.S. was developing new and secret weapons and how we should keep our secrets from the Russians!... Talk like that is a betrayal of those who died or were wounded in this war and of those who are working to make it possible for nations to live in peace with each other. (Litoff and Smith, 1991, Since You Went Away, 279-280)

With the misery and anguish of the Second World War uppermost in their minds, women were inspired to call for a world in which peace would be paramount. In an August 14, 1945 letter to her husband, Rose McClain of Snoqualmie Falls, Washington spoke for many women and men when she expressed the hope that World War II would mark "the end of war for all time," and "that our children will learn kindness, patience, honesty and the depth of love and trust we have learned, from all of this, without the 
tragedy of war." (Litoff and Smith, 1991, Since You Went Away, 273)

\section{Conclusion}

The geographic horizons of women in the United States were significantly altered and expanded by the events of World War II. As both civilian and military women journeyed to distant areas and encountered new people and ways of life, their view of the world was greatly enhanced. Service wives crisscrossed the continent while women who remained at home vicariously followed the journeys of loved ones. Moreover, the changing landscape of rural and urban America prompted women to travel to new locations in search of war-related jobs that expanded their social and economic roles. The nearly 400,000 women who served in the military experienced even greater opportunities for travel and adventure than their civilian counterparts. Often assigned to remotes posts around the world, they encountered different customs, cultures, food, and languages and, when possible, they seized the opportunity to visit local tourist sites.

The unanticipated and far-reaching consequences of enforced wartime travel played an important role in transforming the way American women thought about themselves and their world. Utilizing their augmented geopolitical knowledge, women were better prepared to confront the challenges presented by the postwar world. Although the postwar decade witnessed a renewed interest in motherhood and family that resulted in a return to a more conventional way of life for many women, the extraordinary 
cultural and political changes experienced by these enforced tourists were not forgotten. A generation later, these changes would provide the foundation for the rejuvenation of the woman's movement in the United States, and the legacy of the war continues to reverberate in women's lives.

While this paper has examined the specific travel experiences of United States women during World War II, enforced wartime travel was a global phenomenon that resulted in momentous cultural dislocations and change - significantly more so for women in Europe and Asia than for women from the United States. Whether war refugees, concentration camp inmates, partisans, supporters of the resistance, prisoners of war, women in uniform, or soldiers' wives, millions of women across the globe found themselves caught up in a horrendous war that necessitated that they become enforced tourists.

Much has been written about how major wars, dating as far back as Roman times, have given rise to postwar pilgrimages, battlefield tours, and the establishment of commemorative memorials and museums which, in turn, have had an enormous impact on the tourist industry. (Lloyd, 1998, Piehler, 1995, Turnbridge and Ashworth, 1996, Graham, Ashworth, and Turnbridge, 2000, Wood, 2003) However, with the exception of the work of Robin Gerster and Peter Pierce, the often unanticipated and far-reaching consequences of travel during wartime itself have not been fully explored. (Gerster and Pierce, 2004)

As this paper has demonstrated, the exigencies of World War II resulted in a 
massive expansion of travel opportunities for American women that formed an essential ingredient of their wartime experience. The opportunities for additional studies of travel during wartime abound and will hopefully be replicated for other regions of the world as well as for other times of conflict. Indeed, the far-reaching consequences of wartime travel and the extent to which it transforms the lives of enforced tourists - both women and men, civilian and military - is a largely uncharted topic worthy of considerable attention by scholars. 


\section{REFERENCES}

Allen, M.D.(1998) Less Complicit Than Thou: Feminist Interpretations of Women's Travel Writers. Review 20, 127-140.

Benjamin, L. P. (1943) Safe conduct: The dos and don'ts of keeping him loving you always. Ladies' Home Journal (January), 71, 90.

Bennet, C. (1943) Blue star wife. Cosmopolitan (July), 54-55, 65.

Beveridge, E. (1944) Cooking in cramped quarters. Woman's Home Companion (June), 98-99.

Blunt, A. and Rose, G. (eds) (1994) Writing Women and Space: Colonial Postcolonial Geographies. New York: The Guilford Press, 121-137.

Campbell, D. (1984) Women at War with American: Private Lives in a Patriotic Era. Cambridge: Harvard University Press.

Fowler, B. B. (1943) You're moving July 1. Saturday Evening Post (June 12), 20-21, 105-106.

Gerster, R. and Pierce, P. (2004) On the War-Path: An Anthology of Australian Military Travel. Carlton: Melbourne University Publishing.

Gordon, E. (1943) The triumph of little things. House Beautiful (May), 35, 37, 100-101, 104-105.

Graham, B., Ashworth, G.J. and Turnbridge, J.E. (2000) A Geography of Heritage:

Power, Culture \& Economy. London: Arnold.

Green, M .E. and Murphy, M. (1943) No mama's girls. Saturday Evening Post (April 3), 20-21, 83-84.

Harper, L. M.. (2001) Solitary Travelers: Nineteenth-Century Women's Travel Writing. Madison: NJ: Fairleigh Dickinson University Press.

Hartmann, S. (1982) The Home Front and Beyond: American Women in the 1940s. Boston: Twayne. 
Hohman, L. B. (1943) Don't follow your husband to camp. Ladies' Home Journal (September), 108-109.

Holbrook, C. (1944) You can't take it with you. Better Homes and Garden (July), 18-19.

How to live in a trunk (1942) Good Housekeeping (January), 106-109.

Island of Navy Wives (1942) Saturday Evening Post (September 5), 26-27, 68-69.

Kas, F. and Thompson, B. (1944) A war bride equips her kitchen. Ladies' Home Journal (February), 116.

Kenyon, J. H. (1945) Traveling with baby. Good Housekeeping (January), 59, 142-143.

Klaw, B. (1943) Camp Follower: The Story of a Soldier's Wife. New York: Random House.

Litoff, J. B., et al. (1990) Miss You: The World War II Letters of Barbara Wooddall and Charles E. Taylor. Athens: University of Georgia Press.

Litoff, J. B. and Smith, D. S. (eds) (1991) Dear Boys: World War II Letters from a Woman Back Home. Jackson: University Press of Mississippi.

Litoff, J. B. and Smith , D. S. (1991) Since You Went Away: World War II Letters of American Women on the Home Front. New York: Oxford.

Litoff, J. B. and Smith, D. S. (1993) To the rescue of the crops: Women and United States agriculture during World War II. Prologue (Winter), 346-361.

Litoff, J. B. and Smith, D. S. (1994) We're in This War Too: World War II Letters from American Women in Uniform. New York: Oxford.

Lloyd, D.W. (1998) Battlefield Tourism: Pilgrimage and the Commemoration of the Great War in Britain, Australia and Canada, 1919-1993. New York: Oxford.

Maulsby, A. (1945) War wives: The four types. New York Times Magazine (May 6), 20.

Mayberry, V. (1984) Draftee's wife: A memoir of World War II. Indiana Magazine of History 79 (December), 305-329.

Mills, S.and Foster, S. (eds) (1998) British Women's Travel Writing: An Anthology. Manchester: Manchester University Press. 
Navy wives at Key West (1943) Life(June 2), 58-60.

Office of War Information (1944) A question of wives, Magazine War Guide (October), 27-29.

Packard, V. (1944) Millions on the move. American Magazine (October), 34-36, 97.

Piehler, G. K.(1995) Remembering War the American Way. Washington: Smithsonian Institution Press.

Pilkey, Rita Papers, Blagg-Huey Library, Texas Woman’s University, Denton, Texas, USA.

Pope, V. (1943) War brides. Saturday Evening Post (June 12), 28-29, 84-85.

Pratt, M. (1992) Imperial Eyes: Travel Writing and Transculturation. London: Routledge.

Shultz, G. D. (1945) Hints for tiny travelers. Better Homes and Gardens(June), 40, 98-99.

Shultz, G. D. (1943) If baby must travel. Better Homes and Gardens (July), 30, 59-60.

Siler, T. (1945) Paris: The G.I.'s silver foxhole. Saturday Evening Post (January 27), 2627,66 .

Skult, Molleye Papers, Historical Society of Delaware, Wilmington, Delaware, USA

Smith, S.(2001) Moving Lives: Twentieth-Century Women's Travel Writing. Minneapolis: University of Minnesota Press.

Soldiers' wives give up home and job for camp life with husbands (1942) Life (October 12), 56-62.

Somerville, Keith Frazier (1943) Unpublished Journal.

Sweedy H. B. (1943) I'm following you. New York Times Magazine (October 3), 32.

Turnbridge, J. E. and Ashworth, G. J. (1996) Dissonant Heritage: The Management of the Past as a Resource in Conflict. Chichester: John Wiley \& Sons.

US Department of Labor, Children's Bureau Publication no. 307 [n.d.] If Your Baby Must Travel in Wartime. Washington: Government Printing Office. 
Valentine, E. R. (1944) Odyssey of the Army wife. New York Times Magazine (March 5), 14.

Wesley, M. C. (1999) Secret Journeys: The Trope of Women's Travel in American Literature. Albany, NY: State University of New York Press.

Wood, A. D. W. (producer) (2003) Gold Star Mothers: Pilgrimage of Remembrance, Urbana, IL: WILL-TV.

World War II Letters of United States Women, Bryant University, Smithfield, Rhode Island, USA. 